\title{
PENGARUH PEMBERIAN POC URINE SAPI TERHADAP PERTUMBUHAN BIBIT PINANG BETARA (Areca catechu L.)
}

\author{
Fito Hendriyatno*, Deno Okalia ${ }^{1}$, dan Mashadi* \\ *Prodi Agroteknologi Fakultas Pertanian Universitas Islam Kuantan Singingi Teluk Kuantan \\ Jl. Gatot Subroto KM 7 Jake Tlpn. 085278968217 E-mail : fitohendri793@gmail.com
}

\begin{abstract}
This study has been carried out in villages in the Pulau Kopung Sentajo Kuantan Singingi. A used in this research was 4 months starting july to october 2017. The purpose of this research is to know the influence on the growth of cow urine poc seeds areca palm (areca catechu L.). The design used in this research was a random group: ( $R A K)$ non factorials, where $S$ the (fertilizer poc urine cattle consisting) of the standard treatment 5 S0: without the POC cow urine (control), the S1: POC cow urine $50 \mathrm{ml} /$ liters of water, the cow urine S2: POC $100 \mathrm{ml} /$ liters of water, the S3: POC cow urine $150 \mathrm{ml} /$ liters of water, the cow urine S4: poc $200 \mathrm{ml} /$ liters of water. Data analyzed statistically, by test said different real give an bnj ) the first 5 percent. Parameter examined is high seeds (cm), diameter of the stem $(\mathrm{cm})$, and the number of leaves (strands).Based on the research done that has been done can be concluded that: treatment the provision of organic fertilizers a liquid (POC) urine cattle had have real impact on parameter the number of leaves seeds areca palm but best S3 (the POC urine cattle $150 \mathrm{ml}$ per liter of water) with number of leaves 6,67 strands.
\end{abstract}

Keywords: poc cow urine, growth, seeds, areca palm.

\begin{abstract}
Abstrak. Penelitian ini telah dilaksanakan di Desa Pulau Kopung Kecamatan Sentajo Raya Kabupaten Kuantan Singingi. Waktu yang digunakan dalam penelitian ini adalah 4 bulan yang dimulai bulan Juli sampai Oktober 2017. Tujuan Penelitian ini adalah Untuk mengetahui pengaruh pemberian POC Urine sapi terhadap pertumbuhan bibit pinang (Areca catechu L.). Rancangan yang digunakan dalam penelitian ini adalah: Rancangan Acak Kelompok (RAK) non faktorial, dimana faktor S (Pupuk POC Urine Sapi yang terdiri dari 5 taraf perlakuan yaitu S0 Tanpa pemberian POC Urine Sapi (Kontrol), S1 Pemberian POC Urine Sapi 50 ml/ liter air, S2 Pemberian POC Urine Sapi 100 ml/liter air, S3 Pemberian POC Urine Sapi $150 \mathrm{ml} / \mathrm{liter}$ air, S4: Pemberian POC Urine Sapi $200 \mathrm{ml} /$ liter air. Data-data dianalisis secara statistik, dengan uji lanjut beda nyata jujur (BNJ) pada taraf 5\%. Parameter yang diamati adalah tinggi bibit $(\mathrm{cm})$, diameter batang $(\mathrm{cm})$, dan jumlah daun (helai). Berdasarkan hasil penelitian yang telah dilakukan dapat disimpulkan bahwa: Perlakuan pemberian pupuk organik cair (POC) urin sapi berpengaruh nyata terhadap parameter pengamatan jumlah daun bibit pinang dengan perlakuan terbaik S3 (Pemberian POC Urine Sapi 150 ml/liter air) dengan jumlah daun 6,67 helai.

Kata kunci: POC Urine Sapi, Pertumbuhan, Bibit, Pinang.
\end{abstract}

\section{PENDAHULUAN}

Penggunaan pupuk di dunia terus meningkat sesuai dengan pertambahan luas areal pertanian, pertambahan penduduk, kenaikan tingkat intensifikasi serta makin beragamnya penggunaan pupuk sebagai usaha peningkatan hasil pertanian. Para ahli lingkungan hidup khawatir dengan pemakaian pupuk kimia dapat merusak sifat fisika tanah. Sifat fisika tanah yang jelek ditandai dengan kandungan bahan organik yang sangat rendah (Hendrianto et all. 2019). Kandungan bahan organik tanah menjadi sangat rendah (akan menambah tingkat polusi tanah akhirnya berpengaruh terhadap kesehatan manusia. Penggunaan pupuk kimia secara berkelanjutan menyebabkan pengerasan tanah. Kerasnya tanah disebabkan oleh penumpukan sisa atau residu pupuk kimia, yang berakibat tanah sulit terurai. Sifat bahan kimia adalah relatif lebih sulit terurai atau hancur dibandingkan dengan bahan organik.

Salah satu cara yang dilakukan untuk mengatasi permasalahan di atas adalah dengan memanfaaatkan limbah peternakan menjadi pupuk organik, untuk mencegah semakin merosotnya kesuburan tanah. Pupuk organik padat lebih banyak dimanfaatkan pada usahatani, sedangkan limbah cair (urine) masih belum banyak dimanfaatkan. Urin sapi dapat dimanfaatkan sebagai pupuk organik cair sehingga dapat menjadi produk pertanian yang lebih bermanfaat yang biasa disebut dengan POC urine sapi.

Berdasarkan data dari Direktorat jendral Peternakan dan Kesehatan Hewan 
(2017) populasi sapi di Provinsi Riau dari tahun ketahun mengalami peningkatan, data populasi sapi tahun 2014 yaitu 217.652 ekor, pada tahun 2015 sejumlah 229.634 dan pada tahun 2016 yaitu 238.819. Sedangkan menurut data Dinas Peternakan Kabupaten Kuantan Singingi (2016) data populasi sapi yang ada di Kabupaten Kuantan Singingi berfluktuasi setiap tahunnya, data populasi sapi tahun 2013 yaitu 26.215, mengalami penurunan pada tahun 2014 yaitu 22.075 ekor, dan mengalami peningkatan tahun 2015 yaitu 23. 524 ekor.

Dengan tinggi nya populasi sapi yang ada, maka jumlah limbah peternakan yang dihasillkan juga tinggi yaitu berupa limbah kotoran padat dan urine yang belum termanfaatkan secara optimal. Penggunaan urine ternak merupakan salah satu penerapan zero waste management. Urine ternak yang biasanya dibuang tanpa dimanfaatkan merupakan limbah peternakan yang sangat potensial digunakan sebagai pupuk organik cair. Hasil penelitian yang dilakukan oleh Putranto (2003) bahwa dalam 100 ekor sapi dapat menghasilkan 1.500 liter sampai dengan 2.000 liter urine per hari.

Penggunaan Pupuk organik cair memberikan beberapa keuntungan, misalnya pupuk ini dapat digunakan dengan cara menyiramkannya ke akar ataupun di semprotkan ke tanaman dan menghemat tenaga. Sehingga proses penyiraman dapat menjaga kelembaban tanah. Pupuk organik cair dalam pemupukan jelas lebih merata, tidak akan terjadi penumpukan konsentrasi pupuk di satu tempat, hal ini disebabkan pupuk organik cair $100 \%$ larut. Sehingga secara cepat mengatasi defesiensi hara dan tidak bermasalah dalam pencucian hara juga mampu menyediakan hara secara cepat (Priangga, Suwarno dan Hidayat, 2013).

Urine sapi mengandung unsur hara $\mathrm{N}, \mathrm{P}, \mathrm{K}$ dan bahan organik yang berperan memperbaiki struktur tanah. Urine sapi dapat digunakan langsung sebagai pupuk baik sebagai pupuk dasar maupun pupuk susulan. Phrimantoro (2002), mengatakan penambahan urine sapi sampai hingga beberapa batas tertentu dapat mengaktifkan proses pemanjangan dan pembelahan sel. Samekto (2006), urine sapi adalah bahan organik yang bisa dimanfaatkan menjadi pupuk cair bagi tanaman.

Menurut Lingga (1991) dalam Yuliarti (2009), jenis kandungan hara pada urin sapi yaitu $\mathrm{N}=1,00 \%, \mathrm{P}=0,50 \%$ dan $\mathrm{K}=1,50 \%$. Selain itu urin sapi juga mengandung zat perangsang tumbuh yang dapat digunakan sebagai pengatur tumbuh diantaranya IAA. Lebih lanjut dijelaskan bahwa urin sapi juga memberikan pengaruh positif terhadap pertumbuhan vegetatif tananaman. Karena baunya yang khas, urin sapi juga dapat mencegah datangnya berbagai hama tanaman, sehingga urin sapi juga dapat berfungsi sebagai pengendalian hama tananaman serangga.

Dengan kandungan yang terdapat dalam pupuk organik cair urine sapi, maka urine sapi sangat berpotensi jika digunakan sebagai pupuk dalam pembibitan tanaman. Urine sapi juga merupakan salah satu zat pengatur tumbuh alami yang dapat digunakan, selain relatif lebih mudah diperoleh juga sederhana penggunaannya. Peranan zat pengatur tumbuh pada pembibitan adalah untuk memacu pertumbuhan bibit. Hasil penelitian Rosniawaty, Sudirja dan Afrianto. (2015) bahwa terdapat pengaruh penggunaan urin sapi yang telah difermentasi terhadap luas daun, volume akar dan bobot kering bibit kakao pada umur 16 minggu setelah tanam (mst). Penggunaan urin sapi dengan konsentrasi $25 \%$ dapat menyamai penggunaan pupuk anorganik pada pembibitan kakao.

Jenis tanaman perkebunan lainnya yang memiliki prospek yang cerah adalah tanaman pinang. Pinang sebagai salah satu tanaman palma cukup potensial dan memiliki nilai ekonomi sebagai bahan baku industri kimia dan farmasi. Pemanfaatannya terutama untuk acara 
seperti ramuan sirih pinang, pada upacara adat, atau untuk keperluan rumah tangga (Saka, 2001). Dengan kemajuan ilmu pengetahuan dan teknologi, pemanfaatan tanaman pinang untuk keperluan farmasi dan industri makin berkembang (Maliangkay, 1991). Disamping prospektif untuk ekspor, pinang juga dapat dikategorikan sebagai tanaman perkebunan serbaguna.

Mengingat prospek yang sangat cerah maka tanaman pinang perlu dibudidayakan secara intensif. Untuk menunjang keberhasilan pengembangan pinang khususnya persemaian bibit pinang, perlu adanya kegiatan pemeliharaan yang memadai di pembibitan. Salah satu kegiatan pemeliharaan adalah melakukan pemupukan yang bertujuan untuk menambah unsur hara yang dibutuhkan tanaman. Tanpa adanya penambahan unsur hara melalui pemupukan, pertumbuhan dan perkembangan bibit, yang hanya bergantung pada persediaan hara yang ada di dalam media tanah, akan menjadi lambat.

Varietas yang digunakan dalam penelitian ini adalah varietas pinang Betara. Pinang Betara merupakan varietas unggul pinang pertama di Indonesia. Berdasarkan hasil evaluasi melalui sidang pelepasan tanggal 8 Nopember 2012, populasi pinang Betara telah dilepas sebagai pinang unggul dengan SK MENTAN Nomor 199/Kpts/SR.120/1/2013. Keunggulan pinang ini adalah ukuran buahnya besar. Bayangkan saja, $1 \mathrm{~kg}$ saja hanya terdapat $18-25$ butir. Semetara itu 1 tandan bisa dihasilkan 150 butir dan 1 tahun produksinya 5 - 6 tandan perpohon.

Penelitian ini bertujuan untuk mengetahui pengaruh pemberian POC urine sapi terhadap pertumbuhan bibit pinang Betara (Areca catechu L.)

\section{BAHAN DAN METODE}

Penelitian ini telah dilaksanakan di Desa Pulau Kopung Kecamatan Sentajo Raya Kabupaten Kuantan Singingi. Waktu yang digunakan dalam penelitian ini adalah 4 bulan yang dimulai bulan Juli sampai Oktober 2017 (Jadwal penelitian dapat dilihat pada Lampiran I).

Rancangan yang dipakai dalam penelitian ini adalah: Rancangan Acak Kelompok (RAK) non faktorial, dimana faktor B (Pupuk POC Urine Sapi yang terdiri dari 5 taraf yaitu: S0 Tanpa pemberian POC Urine Sapi (Kontrol), S1 Pemberian POC Urine Sapi $50 \mathrm{ml} /$ liter air, S2 Pemberian POC Urine Sapi $100 \mathrm{ml} / \mathrm{liter}$ air, S3 Pemberian POC Urine Sapi 150 $\mathrm{ml} / \mathrm{liter}$ air, S4 Pemberian POC Urine Sapi $200 \mathrm{ml} /$ liter air

Masing-masing perlakuan terdiri dari 3 kali ulangan. Jumlah plot yang digunakan sebanyak 15 plot, pada masingmasing plot terdiri dari 12 tanaman dan 9 diantaranya dijadikan tanaman sampel. Jumlah tanaman keseluruhan 60 tanaman.

Parameter yang diamati adalah tinggi bibit $(\mathrm{cm})$, diameter batang $(\mathrm{cm})$, dan jumlah daun (helai).

Analisis data dengan menggunakan Rancangan Acak Kelompok. (RAK) Non Faktorial dengan model analisis datanya yaitu:

$$
\mathbf{Y} \mathbf{i j}=\boldsymbol{\mu}+\mathbf{t i}+\mathbf{k j}+\mathbf{E} \mathbf{i j}
$$

Keterangan :

Yij = nilai pengamatan pada satuan perlakuan pada kelompok ke-i, ulangan ke-j

$\mu \quad=$ nilai tengah umum

$\mathrm{Ti}=$ Pengaruh perlakuan ke-i

$\mathrm{Kj} \quad=$ Pengaruh kelompok ke-j

Eijk = Pengaruh galat pada perlakuan ke$\mathrm{i}$, ulangan ke- $\mathrm{j}$

$\mathrm{t} \quad=$ Banyak perlakuan

$\mathrm{n} \quad=$ Banyak ulangan

Jika pada hasil analisis sidik ragam terdapat perlakuan yang berpengaruh nyata terhadap parameter yang diamati maka dilanjutkan dengan uji beda nyata jujur (BNJ) pada taraf 5\%. 


\section{HASIL DAN PEMBAHASAN}

\section{Tinggi Bibit (cm)}

Data hasil pengamatan terhadap parameter tinggi bibit pinang, setelah dilakukan analisis sidik ragam, menunjukkan bahwa perlakuan pemberian POC urin sapi tidak berpengaruh nyata terhadap tinggi bibit pinang. Hasil uji lanjut Beda Nyata Jujur (BNJ) pada taraf 5\% dapat dilihat pada Tabel dibawah ini.

Tabel 1. Rerata hasil pengamatan tinggi bibit pinang umur 12 minggu dengan pemberian POC urin sapi.

\begin{tabular}{ll}
\hline PERLAKUAN (P) & RERATA \\
\hline S0 (Tanpa pemberian POC Urine Sapi) & 32,17 \\
S1 (Pemberian POC Urine Sapi $50 \mathrm{ml} /$ liter air) & 33,39 \\
S2 (Pemberian POC Urine Sapi $100 \mathrm{ml} /$ liter air) & 33,99 \\
S3 (Pemberian POC Urine Sapi $150 \mathrm{ml} /$ liter air) & 34,70 \\
S4 (Pemberian POC Urine Sapi $200 \mathrm{ml} /$ liter air) & 33,87 \\
\hline
\end{tabular}

$\mathrm{KK}=8,89 \%$

Berdasarkan Tabel 1 dapat dilihat bahwa perlakuan pemberian POC urin sapi tidak mempengaruhi tinggi bibit pinang, akan tetapi rerata tinggi bibit yang paling tinggi terdapat pada perlakuan S3 (Pemberian POC Urine Sapi $150 \mathrm{ml} / \mathrm{liter}$ air) yaitu $34,74 \mathrm{~cm}$. Selanjutnya diikuti oleh tinggi bibit perlakuan S2, S4, dan S1. Sedangkan tinggi tanaman yang paling rendah terdapat pada perlakuan S0 (Tanpa pemberian POC Urine Sapi) yaitu tinggi bibit $32,17 \mathrm{~cm}$.

Pemberian POC Urine Sapi 150 $\mathrm{ml} /$ liter air memberikan hasil terbaik untuk tinggi bibit pinang. Hal ini menunjukkan bahwa Pemberian POC Urine Sapi pada konsentrasi ini mampu meningkatkan serapan unsur hara oleh bibit dan kemudian dapat memicu tinggi tanaman. Menurut Wilkins (1992) untuk mengaktifkan pembelahan sel pada jaringan meristem (titik tumbuh) ketersediaan unsur hara yang cukup dan tersedia sangat dibutuhkan untuk pembelahan sel yang menyebabkan bertambahnya tinggi tanaman.

Tingginya konsentrasi hara yang terkandung di dalam POC urine sapi khususnya nitrogen, membuat tanaman merespon dengan baik, sehingga mengalami pertumbuhan yang optimal.
Beradasarkan penelitian Zulkifli (2013), urin sapi yang telah di permentasi dengan EM-4 (Effective Microorganisme-4) mengandung $0.56 \%$ Nitrogen. Sesuai dengan pernyataan Lingga dan Marsono (2004) dalam. Mardalena (2007), bahwa peranan utama dari nitrogen adalah untuk merangsang pertumbuhan secara keseluruhan bagian tanaman, khususnya batang, cabang, dan daun tanaman.

Sutedjo (2002) menambahkan unsur Nitrogen merupakan unsur hara utama bagi pertumbuhan tanaman didalam pembentukan organ vegetatif tanaman seperti daun, batang, dan akar. Kegunaan unsur nitrogen bagi tanaman adalah untuk meningkatkan pertumbuhan tanaman, meningkatkan kadar protein (asam amino) dalam tubuh tanaman dan meningkatkan kulitas tanaman.

Selain Unsur hara N, urin sapi juga mengandung hara $\mathrm{Mg}$ (Magnesium). Menurut Lakitan (2007) Mg berperan sebagai aktivator dari berbagai enzim dalam reaksi fotosintesis yang menyebabkan terpacunya sintesis dan pembelahan dinding sel secara antiklinal sehingga akan mempercepat tinggi tanaman.

Berbagai senyawa dalam bentuk terlarut yang dihasilkan oleh ginjal terkandung dalam urin sapi. Urine 
merupakan produk uraian dari protein didalam tubuh (Dwijoseputro, 1992). Urine sapi mengandung auksin sebagai salah satu zat yang terkandung didalam makanan hijau yang tidak tercerna dalam tubuh sapi dan akhirnya terbuang bersama urin sapi (Supriadji, 1985).

Kandungan auksin yang terdapat pada urine sapi memberikan dampak yang positif terhadap pertumbuhan bibit pinang. Hal ini sesuai dengan pernyataan Ekowahyuni (2002) bahwa Auksin adalah zat aktif dalam meristem perakaran, senyawa ini membantu proses pembiakan vegetatif. Fungsi auksin adalah untuk merangsang pembelahan sel, sintesis DNA kromosom, merangsang pertumbuhan akar lateral. Auksin merupakan salah satu jenis hormon yang dapat memacu pertumbuhan tanaman dengan meningkatkan proses elongasi sel dan perpanjangan batang seperti halnya diferensiasi sel. Didukung dengan pendapat Campbell, Reece, Mitchell, and Taylor (2003) bahwa auksin dapat mempengaruhi pemanjangan sel-sel tanaman sehingga memicu pertumbuhan tinggi tanaman.

Ditambahkan oleh pernyataan Heddy (1986) menyatakan bahwa auksin dalam tanaman berperan dalam perpanjangan sel dengan cara mempengaruhi metabolisme dinding sel, sehingga terjadi pelunakan dinding sel yang mengakibatkan kemampuan dinding sel mengembang meningkat, sehingga tanaman akan bertambah tinggi.

Rerata tinggi bibit pinamg yang paling rendah terdapat pada perlakuan kontrol S0 (Tanpa pemberian POC Urine Sapi) yaitu $32,17 \mathrm{~cm}$. Hal ini terjadi karena tanaman pada perlakuan kontrol ini tumbuh alami tanpa adanya pemberian pupuk organik cair, sehingga pertumbuhannya lebih lambat dibandingkan perlakuan lain, karena tanaman tumbuh tanpa mendapatkan asupan hara tambahan dari luar. Hal ini sesuai dengan pendapat Sarief (1985) menyatakan, tanaman yang kekurangan unsur hara menyebabkan perkembangannya lebih lambat akan tetapi sebaliknya apabila unsur hara yang diberikan sesuai dengan dosis maka tanaman akan tumbuh dengan baik.

Hasil rerata tinggi bibit pinang perlakuan $\mathrm{P} 0, \mathrm{P} 1, \mathrm{P} 2, \mathrm{P} 3$ dan $\mathrm{P} 4$ adalah $32,17 \mathrm{~cm}, 33,39 \mathrm{~cm}, 33,99 \mathrm{~cm}, 34,70 \mathrm{~cm}$, dan $33,87 \mathrm{~cm}$. Hasil rerata ini tidak berbeda jauh dengan rerata tinggi bibit pinang hasil penelitian Ispantri (2018), dengan perlakuan pemberian pupuk kompos jerami padi terhadap pertumbuhan bibit pinang betara (Areca catechu L.) menghasilkan rerata tinggi bibit pinang perlakuan P0 (Tanah Top soil), P1 (Top soil $+25 \%$ Pupuk kompos jerami padi), P2 (Top soil $+50 \%$ Pupuk kompos jerami padi), P3 (Top soil $+75 \%$ Pupuk kompos jerami padi), dan P4 (100\% Pupuk Kompos Jerami Padi) berturut- turut yaitu $30,22 \mathrm{~cm}, 30,56 \mathrm{~cm}, 32,78 \mathrm{~cm}, 34,11 \mathrm{~cm}$, dan $34,44 \mathrm{~cm}$.

\section{Diameter Batang (cm)}

Data hasil pengamatan terhadap parameter diameter batang bibit pinang, setelah dilakukan analisis sidik ragam, menunjukkan bahwa perlakuan pemberian POC urin sapi tidak berpengaruh nyata terhadap diameter batang bibit pinang. Hasil uji lanjut Beda Nyata Jujur (BNJ) pada taraf 5\% dapat dilihat pada Tabel dibawah 2 . 
Tabel 2. Rerata hasil pengamatan diameter batang bibit pinang umur 12 minggu setelah tanam dengan pemberian POC urin sapi.

\begin{tabular}{ll}
\hline PERLAKUAN (P) & RERATA \\
\hline S0 (Tanpa pemberian POC Urine Sapi) & 0,98 \\
S1 (Pemberian POC Urine Sapi $50 \mathrm{ml} /$ liter air) & 1,00 \\
S2 (Pemberian POC Urine Sapi $100 \mathrm{ml} /$ liter air) & 1,05 \\
S3 (Pemberian POC Urine Sapi $150 \mathrm{ml} /$ liter air) & 1,02 \\
S4 (Pemberian POC Urine Sapi $200 \mathrm{ml} /$ liter air) & 1,01 \\
\hline KK $=9,45 \%$ & \\
\hline
\end{tabular}

Berdasarkan Tabel 2 dapat dilihat bahwa perlakuan pemberian POC urin sapi terhadap diameter batang bibit pinang tidak memberikan pengaruh yang nyata, dengan diameter batang terbesar terdapat pada perlakuan S2 (Pemberian POC Urine Sapi $100 \mathrm{ml} /$ liter air) yaitu $1,02 \mathrm{~cm}$. Selanjutnya diikuti oleh perlakuan S3, S4, $\mathrm{S} 1$, dan diameter tanaman yang paling kecil terdapat pada perlakuan Kontrol S0 (Tanpa pemberian POC Urine Sapi).

Diameter batang terbesar terdapat pada perlakuan S2 (Pemberian POC Urine Sapi $100 \mathrm{ml} /$ liter air) , dimana ini merupakan POC urin sapi konsentrasi sedang sehingga jumlah hara yang diserap tanaman melalui pemberian pupuk organik cair urine sapi ini telah dapat diserap tanaman dengan optimum, terutama kandungan kalium yang berdampak terhadap diameter batang. Hal ini sesuai dengan hasil penelitian Zulkifli (2013), bahwa POC urine sapi mengandung 1,27\% Kalium. Hardjadi (1979) mengatakan bahwa tanaman akan tumbuh subur bila unsur hara yang dibutuhkan tersedia dalam bentuk yang dapat diserap oleh tanaman sesuai dengan kebutuhannya.

$$
\text { Pentingnya kalium dalam }
$$

pertumbuhan diameter batang berhubungan dengan fungsi kalium untuk meningkatkan kadar sclerenchyma pada batang, sclerenchyma mempunyai fungsi member penebalan dan kekuatan pada jaringan batang sehingga tanaman lebih kuat dan tidak mudah rebah. Bel dan Rahmaniah (2001) menyatakan bahwa pertumbuhan tanaman berkolerasi dengan penambahan konsentrasi kalium pada daerah pembesaran. Bila tanaman kekurangan kalium maka pembesaran dan perpanjangan sel terhambat. Ditambahkan oleh Novizan (2002) menyatakan bahwa kalium dapat meningkatkan fotosintesis tanaman melalui peningkatan fotofosforilasi yang menghasilkan ATP dan NADPH yang berperan dalam proses fotosintesis dan metabolism tanaman.

Hal ini sesuai dengan pendapat Abidin (1985) bahwa dengan adanya unsur hara yang tersedia maupun yang tersimpan dalam tanah dapat meningkatkan laju fotosintesis dan akan meningkatkan bahan organik dalam tanaman itu sendiri dapat meningkatkan laju fotosintesis dan akan meningkatkan serapan bahan organik sehingga mempercepat pertumbuhan. Menurut Schroth dan Sinclair (2003) tanaman yang memperoleh unsur hara dalam jumlah yang optimum serta waktu yang tepat, maka akan tumbuh dan berkembang secara maksimal.

Hasil analisis data menunjukkan diameter batang terkecil terdapat pada perlakuan S0 (Kontrol). Hal ini terjadi karena tanpa pemberian pupuk organic cair, pertumbuhan bibit tidak optimum karena kebutuhan unsur hara tanaman tidak terpenuhi. Sesuai pendapat Rismunandar (1986) bahwa dengan terpenuhinya kebutuhan hara tanaman baik unsur makro maupun mikro, maka perkembangbiakan dan produktivitas tanaman akan berjalan lancar dan sebaliknya jika kebutuhan hara tanaman 
tidak terpenuhi, maka perkembangbiakan dan produktivitas tanaman akan terhambat.

Dari hasil rerata diameter batang bibit pinang pada penelitian ini perlakuan S0, S1, S2, S3, dan S4 berturut- turut yaitu $0,98 \mathrm{~cm}, 1,00 \mathrm{~cm}, 1,05 \mathrm{~cm}, 1,02 \mathrm{~cm}$, dan $1,01 \quad \mathrm{~cm}$.. Hasil rerata berbeda dibandingkan dengan rerata diameter bibit pinang hasil penelitian Ispantri (2018), dengan perlakuan pemberian pupuk kompos jerami padi terhadap pertumbuhan bibit pinang betara (Areca catechu L.) menghasilkan diameter bibit pinang perlakuan perlakuan P0 (Tanah Top soil), P1 (Top soil $+25 \%$ Pupuk kompos jerami padi), P2 (Top soil $+50 \%$ Pupuk kompos jerami padi), P3 (Top soil $+75 \%$ Pupuk kompos jerami padi), dan P4 (100\% Pupuk Kompos Jerami Padi) berturut-turut adalah $1,32 \mathrm{~cm}, 1,33 \mathrm{~cm}, 1,40 \mathrm{~cm}, 1,41$ $\mathrm{cm}$, dan $1,45 \mathrm{~cm}$.

\section{Jumlah Daun (helai)}

Data hasil pengamatan terhadap parameter jumlah daun bibit pinang, setelah dilakukan analisis sidik ragam, menunjukkan bahwa perlakuan pemberian POC urin sapi berpengaruh nyata terhadap jumlah daun bibit pinang. Hasil uji lanjut Beda Nyata Jujur (BNJ) pada taraf 5\% dapat dilihat pada Tabel 3.

Tabel 3. Rerata hasil pengamatan jumlah daun bibit pinang umur 12 minggu setelah tanam dengan pemberian POC urin sapi.

\begin{tabular}{ll}
\hline PERLAKUAN (P) & RERATA \\
\hline S0 (Tanpa pemberian POC Urine Sapi) & $5,44 \mathrm{~b}$ \\
S1 (Pemberian POC Urine Sapi $50 \mathrm{ml} /$ liter air) & $5,78 \mathrm{ab}$ \\
S2 (Pemberian POC Urine Sapi $100 \mathrm{ml} /$ liter air) & $6,22 \mathrm{ab}$ \\
S3 (Pemberian POC Urine Sapi $150 \mathrm{ml} /$ liter air) & $6,67 \mathrm{a}$ \\
S4 (Pemberian POC Urine Sapi $200 \mathrm{ml} /$ liter air) & $6,00 \mathrm{ab}$ \\
\hline KK= 5,89\% & BNJ S $=1,00$
\end{tabular}

Keterangan:Angka-angka pada baris dan kolom yang diikuti huruf kecil yang sama tidak berbeda nyata menurut uji lanjut beda nyata jujur (BNJ) pada taraf 5\%.

Berdasarkan Tabel 3 dapat dilihat bahwa perlakuan pemberian pupuk organik cair (POC) urin sapi terhadap jumlah daun bibit pinang memberikan pengaruh yang nyata. Jumlah daun bibit pinang paling banyak terdapat pada perlakuan S3 (Pemberian POC Urine Sapi 150 ml/liter air) yaitu 6,67 helai daun. Perlakuan S3 tidak berbeda nyata dengan perlakuan yaitu S2, S4, dan S1 namun berbeda nyata dengan perlakuan So. Perlakuan S0 merupakan jumlah daun yang paling sedikit yaitu 5,44 helai daun.

Banyaknya jumlah daun yang terdapat pada perlakuan S3 (Pemberian POC Urine Sapi $150 \mathrm{ml} / \mathrm{liter}$ air), hal ini disebabkan karena pemberian pupuk organik cair urin sapi pada konsentrasi ini, dimana hara yang terkandung dalam pupuk organik cair telah dapat diserap dengan baik oleh bibit pinang sehingga memberikan pengaruh yang nyata terhadap parameter jumlah daun bibit pinang. Diantara hara yang terkandung dalam pupuk organik cair merupakan hara yang berperan dalam pembentukan daun.

Salisbury dan Ross (1995) menyatakan bahwa pupuk organik cair selain mengandung nitrogen juga mengandung unsur hara mikro antara lain unsur $\mathrm{Mn}, \mathrm{Zn}$, dan B. Unsur hara mikro tersebut berperan sebagai katalisator dalam 
proses sintesis protein dan pembentukan klorofil. Hal ini didukung dengan penelitian Puspita et al. (2014) yang menyatakan rerata jumlah daun pada perlakuan 20.000 ppm biourin sapi dan 75 $\mathrm{kg} \mathrm{N}$ ha-1 (Urea $110 \mathrm{~kg}$ ha-1 + pupuk kandang sapi 5 t ha- 1) lebih tinggi yakni 7,75 helai dibandingkan perlakuan 10.000 ppm biourin sapi $+50 \mathrm{~kg} \mathrm{~N}$ ha-1 (pupuk kandang sapi 10 t ha-1) yakni 5,17 helai.

Fungsi urine sapi yang lain adalah bekerja sebagai perangsang dalam memacu pertumbuhan bibit pinang. Sesuai dengan pernyataan Sutedjo (2002), bahwa pupuk kandang cair urine sapi selain dapat bekerja cepat, juga mengandung hormon tertentu yang nyata dapat merangsang perkembangan tanaman.

Jumlah daun paling sedikit terdapat pada perlakuan tanpa pemberian urine sapi (kontrol), hal ini terjadi karena bibit tumbuh alami tanpa pemberian pupuk sehingga pertumbuhannya lebih lambat dibandingkan perlakuan lain dan jumlah daun yang dihasilkan tanaman lebih sedikit. Lingga dan Marsono (2004), menambahkan bahwa kebutuhan tanaman terhadap unsur hara, bila pemberiannya kekurangan tanaman justru akan mengalami gangguan metabolisme, bahkan menyebabkan tanaman gagal dalam pertumbuhannya.

Dari hasil rerata jumlah daun bibit pinang pada penelitian ini perlakuan S0, S1, S2, S3, dan S4 berturut- turut yaitu 5,44 helai, 5,78 helai, 6,22 helai, 6,67 helai, dan 6,00 helai. Hasil rerata berbeda dibandingkan dengan rerata diameter bibit pinang hasil penelitian Ispantri (2018), dengan perlakuan pemberian pupuk kompos jerami padi terhadap pertumbuhan bibit pinang betara (Areca catechu L.) menghasilkan diameter bibit pinang perlakuan perlakuan P0 (Tanah Top soil), P1 (Top soil $+25 \%$ Pupuk kompos jerami padi), P2 (Top soil $+50 \%$ Pupuk kompos jerami padi), P3 (Top soil $+75 \%$ Pupuk kompos jerami padi), dan P4 (100\% Pupuk Kompos Jerami Padi) berturut-turut adalah 9,00 helai , 9,44 helai , 10,00 helai, 10,11 helai, dan 11,44 helai.

\section{SIMPULAN}

Berdasarkan hasil penelitian yang telah dilakukan dapat disimpulkan bahwa: Perlakuan pemberian pupuk organik cair (POC) urin sapi berpengaruh nyata terhadap parameter pengamatan jumlah daun bibit pinang dengan perlakuan terbaik S3 (Pemberian POC Urine Sapi $150 \mathrm{ml} / \mathrm{liter}$ air) yaitu jumlah daun 6,67 helai.

\section{DAFTAR PUSTAKA}

Abidin, Z. 1985. Dasar-Dasar Pengetahuan Tentang Zat Pengatur Tumbuh. Angkasa. Bandung.

Bel dan A.A. Rahmania, 2001. Telaah Faktor Pembatas Kacang Tanah. Penelitian Palawija. http://docs.google.com. Diakses 14 April 2017.

Dinas Peternakan Kabupaten Kuantan Singingi. 2016. Kuantan Singingi dalam Angka. Laporan Tahunan Dinas Peternakan Kabupaten Kuantan Singingi.

Direktorat jendral Peternakan dan Kesehatan Hewan (2017). Data Populasi Sapi Setiap Provinsi yang ada di Indonesia.

Djiwosaputro, D., 1992. Pengantar Fisiologi Tumbuhan. Gramedia, Jakarta.

Ekowahyuni, L.P., 2002. Fenomena vivipary labu siam (sechium edule jacq swartz) varietas lokal desa Barukupa Bawah Cipanas. Makalah falsafah sains (pps 702). Institut Pertanian Bogor. Bogor.

Ispantri. 2018. Uji pemberian pupuk kompos jerami padi terhadap pertumbuhan bibit pinang betara (Areca catecu L.). Skripsi. Program Studi Agroteknologi Fakultas Pertanian Universitas Islam Kuantan Singingi. Teluk Kuantan.

Heddy, S. 1986. Hormon Tumbuhan. CV. Rajawali. Jakarta. 95 hal. 
Hendrianto A, Okalia D, Mashadi. 2019. Uji Beberapa Sifat Fisika Tanah Bekas Tambang Emas Tanpa Izin (PETI) Di Tiga Kecamatan Di Daratan Sepanjang Sungai Kuantan. Juatika: Jurnal Agronomi Tanaman Tropika 1(1):19-31 (https://doi.org/10.36378/juatika.v1i1. 41)

Lakitan, B. 2007. Fisiologi Tumbuhan dan Perkembangan Tanaman. Jakarta. PT Raja Grafindo Persada. 28 hal.

Lingga, 1991. Petujuk penggunaan Pupuk. Penebar Swadaya. Jakarta.

Lingga dan Marsono, 2004. Petunjuk Penggunaan Pupuk. Redaksi Agromedia, jakarta.

Maliangkay. 1991. Manfaat Tanaman Pinang (Areca catechu L). Buletin Balitka No. 15 September: 64 - 72.

Mardalena. 2007. Respon pertumbuhan dan produksi tanaman mentimun (Cucumis sativus L.) terhadap urine sapi yang telah mengalami perbedaan lama fermentasi. Skripsi. Fakultas Pertanian Universitas Sumatra Utara. Medan.

Novizan. 2002. Petunjuk Pemupukan Yang Efektif. Agromedia Pustaka. Jakarta. 25 hal.

Phrimantoro . 2002. Pemanfaatan Pupuk Kandang. Kanisius Yogyakarta.

Priangga, R, Suwarno and Hidayat, N. 2013. Pengaruh level pupuk organik cair terhadap produksi bahan kering dan imbangan daun-batang rumput gajah defoliasi keempat.Jurnal Ilmiah Peternakan. Universitas Jenderal Soedirman, Purwokerto. 1(1):365-373.

Putranto, A.T.S.A, 2003. Pemanfaatan urine sapi Bali untuk pembuatan pupuk organik cair di Dusun Ngandong, Desa Girikerto, Kecamatan Turi, Kabupaten sleman Daerah Istimewa Yogyakarta. Program Pasca Sarjana Universitas Gajah Mada Yogyakarta.
Puspita, P. B.; Sitawati; dan M. Santosa. 2014. Pengaruh Biourie Sapi dan Berbagai Dosis Pupuk $N$ Terhadap Tanaman Kailan (Brassica oleraceae L.). J. Produksi Tanaman. 3(1):1-8.

Rismunandar. 1986. Tanah dan selukbeluknya bagi pertanian. Sinar Baru. Bandung. $107 \mathrm{hlm}$.

Rosniawaty, S., R. Sudirja dan H. Afrianto. 2015. Pemanfaatan Urin Kelinci dan Urin Sapi sebagai Alternatif Pupuk Organik Cair pada Pembibitan Kakao (Theobroma cacao L.). Jurnal Kultivasi. Volume 14 No 1. Maret 2015.

Saka. N. T. 2001. Etnobotani Sirih-Pinang dalam kehidupan Suku Ruteng di Kabupaten Manggarai. Program Pascasarjana IPB. Bogor.

Salisbury, F. B. dan C. W. Ross. 1995. Fisiologi Tumbuhan. Jilid I. Edisi IV. ITB, Bandung.

Sarief, S. 1985. Kesuburan dan Pemupukan Tanah Pertanian. Pustaka Buana. Bandung.

Schroth \& Sinclair (Eds). (2003). Trees, crops and soil fertility : concepts and research methods. Cambridge: CABI Publishing.

Sutedjo, M.M. 2002. Pupuk dan Cara Pemupukan. PT Rineka Cipta. Jakarta.

Yuliarti. N., 2009. Kompos. C.V ANDI OFSET. Yogyakarta Budianta. 2004. Manfaat EM-4 Dalam Meningkatkan Pertumbuhan dan Produksi. Penebar swadaya. Jakarta.

Wilkins, M.B., 1992. Fisiologi Tanaman. Penerjemah Sutedjo M.M dan Kartasapoetra A.G. penerbit Bumi Aksara: Jakarta.

Zulkifli. 2013. Uji Fermentasi Kotoran Sapi Menggunakan EM4 (Effective Microorganisme4) Terhadap Kualitas Pupuk Organik cair. Skripsi SI Jurusan Agroteknologi sekolah Tinggi Ilmu Pertanian Swarnadwipa. Teluk Kuantan. 